\title{
EFFECT OF MEDICAL WASTE ON HEALTH OF POPULATION AND ENVIRONMENT IN THE REPUBLIC OF SERBIA
}

\author{
Milica Marceta', ImreNadj ${ }^{2}$ \\ Received: June 25, 2018 | Accepted: November 4, 2018
}

\begin{abstract}
The paper presents problems of care and the current state of the impact of medical waste on human health and the environment in the selected area of the Republic of Serbia. In general environmental pollution, medical waste does not take up much, but its specific characteristics are potentially among the most dangerous types of waste. Inadequate care can affect the health of the medical workers, the population and the surrounding areas in which the waste is stored, but also lead to outbreaks of global infection and poisoning. In order to testing the current state of the impact of medical waste on human health, and the possible unwanted consequences that it can produce, if it is treated in an inappropriate manner, a survey was conducted in the rural and urban environment. Research has shown that most of the respondents, unused drugs throw away into a garbage, which is mixed with municipal waste, and without prior separation it is deposited on the city landfill, and according to the Likert scale, more than $50 \%$ of the respondents partially or completely agree with the claim that the unorganized landfills are not sufficiently safe and pose a risk for the possible spread of the disease, as well as that no containers are placed in the public places for the disposal of medical (pharmaceutical) waste. Respondents believe that the Ministry of Health and the Ministry of Environmental Protection should take responsibility for the safe management of medical waste, where over $80 \%$ of respondents expressed their willingness to store drugs at suitable locations in their places.
\end{abstract}

Key words: medical waste, environment, health of the population

\footnotetext{
University of Belgrade, Faculty of Geography, e-mail: milica0210@gmail.com

University of Novi Sad, PMF, Department of Geography, Tourism and Hotel Management, Novi Sad, imre.nadj@dgt.uns.ac.rs
} 


\section{INTRODUCTION}

With the development of human society, all the larger quantities of waste accumulate, endangering human health and environment. Pollutant substances transmitted through the food chain, through the ultimate consumer, man/person. Causative-consequently, man with his negligible action, pollutes the air, water, soil, and such products with the food chain reach into various food products. Numerous metals as a result of various emissions from industry and traffic polluting the environment and thus becoming the major source of hazardous waste generation. By developing cities and industries, by increasing the number of inhabitants and consumption, a large amount of municipal waste is generated which needs to be controlled, delayed,and constantly studied, with the quantification of possible negative impacts on the health of the population.

\section{DEFINING DANGEROUS WASTE}

Hazardous waste is a waste containing ingredients that can cause permanent or temporary damage to health and the environment. It is any waste containing substances with one of the following properties: toxicity, carcinogenicity, mutagenicity, reactivity, explosiveness, infectivity, irritability, ecotoxicity, the characteristic of the oxidation and release of toxic gases by chemical reaction or biological degradation (Law on waste management, 2009).

According to EU standards and one of the most important conventions of the UN Environment Program - the Basel convention ${ }^{1}$, adopted in 1989, hazardous waste is defined as substances or objectswhich are disposed according to special procedures, in accordance with national legislation. The Basel convention and I, II, III and IV annexes regulate the definition of hazardous waste, category and character, where medical waste is defined and placed in the first place (belongs to the group of hazardous waste). In the Republic of Serbia since 2000, the Basel convention on transboundary movement of waste has been applied. The text of this convention defines the most important goal for ecologically rational management of hazardous waste (Jovanovic, 2014).

In 1944. the European Commission was defined the European waste catalog, where waste is defined on the basis of three criteria:

1. The origin of waste, the definition of an industrial branch or sector from which the waste originates (the first two digits - the health sector - 18)

1 Basel Convention on the Control of Transboundary Movement of Hazardous Waste and its Disposal. The convention was adopted in 1989, as one of the international legal acts in the area of hazardous waste management, which regulates cross-border movement and disposal of medical waste as a type of hazardous waste. The Convention has been signed by more than 100 countries, which accept the principle that the only legitimate transport of hazardous waste, exports from countries that do not have facilities or professional staff for reliable waste disposal, to countries with facilities and professional staff (National guide for the safe management of medical waste, 2008). 
2. The process duringwhich waste occurs (waste that occursin providing health services, in diagnostics, treatment,disease prevention in humans, in maternity clinics, other two digits - 18 01)

3. Waste type (third pair of digits - non-hazardous waste - waste whose collection and disposal is not subject to special requirements for the prevention of infections, 180104$)$.

If certain categories of waste next to the number with 6 digits have a star behind the last digit, star indicates that this waste belongs to hazardous waste (example: $180103^{*}$ infectious waste, National waste management guide, 2008).

\section{MEDICAL WASTE MANAGEMENT}

Based on the adopted Law on waste management in the Republic of Serbia from 2009, the term medical waste means "waste generated from facilities where health care is provided to people or animals and / or from other places where health services are provided (from diagnostics, experimental work, laboratory, cleaning, maintenance and disinfection of space and equipment), including non-hazardous and hazardous medical waste, as follows:

- non-hazardous medical waste (not contaminated with dangerous or other substances, which is similar to municipal waste - biodegradable, recyclable);

- hazardous medical waste (it has one or more hazardous characteristics that make it hazardous: patoanatomic waste, sharp objects, pharmaceutical waste, including cytotoxic and cytostatic waste, waste contaminated with blood and body fluids, infectious, other hazardous medical waste - chemical waste, waste with high contents of heavy metals and waste bottles under pressure ") (Law on waste management, 2009).

Medical waste management is a set of measures that include the collection, sorting, packaging, marking, storage, transport, treatment or safe disposal of medical waste (Ordinance on medical waste management, 2010). One part (10-25\%) of medical waste represents hazardous waste for human health and the environment.

According to the European waste catalog, medical waste is registered under number 180000 with subdivisions. Subsection no. 18 01: Waste from hospitals and / or health centers, waste arising from the diagnosis, in the prevention of human health, waste treatment. 
Table 1: Excerpt from the Catalog waste with the described categories of waste

\begin{tabular}{|l|l|}
\hline $180101^{*}$ & Sharp objects (except 18 01 03*) \\
\hline 180102 & $\begin{array}{l}\text { Parts of bodies and organs, including blood bags and blood derivatives (except 18 01 } \\
\text { 03*) }\end{array}$ \\
\hline $180103^{*}$ & $\begin{array}{l}\text { Infectious waste, waste whose collection and disposalis subject to special } \\
\text { requirements to prevent infection }\end{array}$ \\
\hline 180104 & $\begin{array}{l}\text { Non-infectious waste(waste whose collection and disposalis not subject to special } \\
\text { requirements to prevent infection, for example:curves, plaster, diapers, bed sheets, } \\
\text { disposable clothing) }\end{array}$ \\
\hline $180106^{*}$ & Chemical waste containing hazardous substances \\
\hline 180107 & Other chemical waste \\
\hline $180108^{*}$ & Cytotoxic drugs and cytostatics \\
\hline 180109 & Drugs other than those listed in 180108 \\
\hline 180110 & Amalgam waste from dental care \\
\hline
\end{tabular}

Source: Ordinance on conditions and manner of classification, packaging and storage of secondary raw materials, Official Gazette of the Republic of Serbia, no. 55/2001)

In the framework of health institutions, different types of medical infectious waste are created: hazardous medical waste and inert medical waste - municipal. Hazardous medical waste is further divided into: pathohistological (means tissues taken for medical purposes, parts of the human body, tissues and organs removed by surgical procedures, placenta and fetuses, blood and body fluids, animals used for testing and their parts of the body), infectious waste accounts to $20 \%$ of the total waste from a healthcare facility (material and accessories that came into contact with the blood or secretions of infectious patients or used in autopsies, wound healing, during surgical procedures, waste from the dialysis department, gloves, infusion system, tissues material with visible blood presence, used swabs, needles and syringes after parenteral drug delivery, disposable scalpels, paper towels with traces of blood, waste containing pathogenic biological agents that can cause disease due to excessive concentration or number), pharmaceutical waste (cytotoxic drugs, antiviral agents, anti-infective agents, hormones, toxins, irregular drugs, vaccines, serums due to the expiry date, spillage or altered organoleptic properties, their primary packaging, equipment used in handling - bottles, boxes, masks, tubes, gloves), sharp objects (needles, scalpels), chemical waste (pressure vessels, flammable and toxic substances, chemicals that are disposed during the diagnostic and cytostatic waste (waste with carcinogenic, mutagenic or teratogenic properties - cytostatics), radioactive waste (waste contaminated with radionuclides, diagnosis, therapy, research) and the inert medical waste (generated in kitchens and restaurants -it is disposed of as household waste, and does not pose a risk to health and the environment) (Saric, Knezevic, 2009).

According to the EU legislation, the World Health Organization (WHO), National waste management strategy from 2003 and the Regulation on the disposal of waste to landfills, one of the priority tasks of each healthcare institution in the country is the adoption of Guidelines about mandatory treatment with potentially infectious and infectious 
medical and pharmaceutical waste, as well as the Management Plan for hazardous medi$\mathrm{cal}$ and pharmaceutical waste ${ }^{2}$. Given that there is no adequate treatment for this type of waste for hazardous pharmaceutical waste in our country, it is exported to EU countries that have the appropriate incinerator to destroy it in a special way. Thus, the Agency for medicinal products and medical devices in Belgrade, destroys pharmaceutical waste at the insiner in Vienna. Before exporting, by an authorizedorganization the waste statement Report is submitted. The export of hazardous waste, which is carried out in accordance with the Basel convention, follow the Document on the movement of hazardous waste signed by anyone who takes the waste. A permit for export of waste is obtained from the Ministry of environmental protection, Customs administration and relevant institutions of those countries through which such waste passes (Bozic, 2013).

Before transportation of medical waste, in every healthcare it is necessary to purchase consumable materials (bags and boxes for infectious medical waste, buckets with a lid and pedal, containers and labels with the declaration of each individual packaging) and their location at the appropriate places within the institution. It is very important that all containers are properly closed,all for the purpose of disabling availability of medical waste to transmitters of diseases - insects and rodents (Institute of public health of Serbia “Dr Milan JovanovicBatut”, 2009).

\section{CURRENT SITUATION OF MEDICAL WASTE MANAGEMENT IN THE REPUBLIC OF SERBIA AND OTHER COUNTRIES}

Ministry of Health of the Republic of Serbia in 2007 was launched the project "Technical support in the management of medical waste", funded by the EU. On this occasion, the donation provided 55 health institutions with autoclaves and crushers, 25 medical institutions with vehicles for the transport of infectious medical waste, supply of consumables for the separation of infectious medical waste as well as the purchase of additional number of crushers for institutes and public health institutes - a total of 78 autoclaves and 78 crusher (National guide for safe management of medical waste, 2008).

According to existing data from the health sector, about $10-25 \%$ of medical waste makes hazardous waste that is risky for the health of the population and the environment. Hospitals in Serbia have 50,988 beds, average occupancy rate of $72 \%$ and number of 15 million hospital days. An additional 2,700 beds are in military hospitals and private clinics. It is estimated that all health institutions in Serbia produce about 48,000 tons of medical waste annually, of which 9,600 tons of infectious waste. The average amount of hazardous infectious medical waste, excluding the private sector and the veterinary medicine sector, is 0.7 $\mathrm{kg}$ of waste per bed per day (Serovic, 2011). The amount of waste in hospitals depends on

2 Pharmaceutical factory "Hemofarm" Vrsac deals with the production of quality, efficient, safe pharmaceutical products using modern technology. It belongs to the so-called white industrial producers who are not huge waste generators. In 2016, it generated a total of 808 tons of industrial waste, of which 167 tons of hazardous waste was destroyed by the incineration in Germany and Austria. Of the total hazardous waste, Hemofarm was independently carried out over 93 percent after obtaining the license for independent export from the competent Ministry (Sustainable Development Report of Hemofarm, 2016). 
the level of national income, type of illness, number of beds and type of facility. In developed countries, health facilities, hospitals can produce up to $10 \mathrm{~kg}$ of waste per bed per day - all categories of medical waste combined (Medical waste management, 2011). Certain categories of medical waste, primarily infectious waste, pose a serious risk to the health of employees in health care institutions as a result of direct contact. Of course, and indirectly, medical waste cannegatively affect human and animal health through contaminated watercourses and land, as well as through polluted air through the emission of highly toxic gases after incineration.Under conditions where the waste is burned at low temperatures or when plastic is burned which contain polyvinyl chloride can produce polychlorinated biphenyls, dioxins, furans and other toxic aeropolutans classified as carcinogens, heavily degradable in the environment and bioaccumulated in the food chain. Some healthcare institutions use a method of burning medical waste in their own incinerators, however, since the incinerators work at temperatures that are not adequate for the safe burning of medical waste, there is a presumption and a justified possibility for additional control and closure of them. In some healthcare institutions, infectious medical waste is sterilized by water vapor under increased pressure in autoclaves ${ }^{3}$, where after sterilization it is disposed of in a regular municipal waste container. If infectious waste is first sterilized, and then trash to the smallest detail, then it can be deposited in landfills as municipal waste. What is worrying is the fact that in some healthcare institutions, used sharp objects, syringes, needles, curves are not separated or sterilized, but they are mixed with municipal waste and so they are deposited on the city landfill. Containers are located in uninhabited spaces, open and easily accessible to anyone. Waste is often burnt in illegal incinerators, without control, and in some cases waste without prior processing together with municipal waste relates to landfills or is discharged into city sewerage systems. Employees on this type of work are not adequately protected, without additional education and therefore exposed to the negative effects of this type of waste (National guide for safe management of medical waste, 2008).Incorrect handling and disposal of medical waste can lead to physical injury through contaminated sharp objects and hence to infection with Hepatitis B, C and HIV (Ali Khan, 2006). Direct risks include the transmission of disease by the vector and the pollution of water and the environment (http://ec.europa.eu/echo/files/evaluation/ watsan2005/annex_files/WEDC/es/ES08CD.pdf).

Indeed this can lead to the spread of infectious diseases through the direct contact of employees and people who collect waste at landfills, with the help of animals and birds (vectors) which through the landfill are roam in search of food as well as microorganisms through the air (through the emission caused by the tinting of the burning waste) (Jovanovic, 2014). A number of facilities for the treatment of medical infectious waste - autoclaves and crushers for various reasons (lack of space, training, frequent breakdowns) work occasionally or do not work, and private medical institutions are not included in the mentioned treatment facilites system. In accordance with international regulations and laws, developed countries have modern devices for the treatment of hazardous medical waste (autoclave and inciner-

3 Steam disinfection / sterilization or autoclaving involves thermal treatment under strictly controlled operating conditions (pressure, temperature, water vapor saturation, duration, etc.) which result is a safe level of sterility of 105 or fewer microorganisms (Ordinance on medical waste management, 2010). 
ator), where they respect principles of protecting the human health and the environment: waste prevention, waste reduction, control of possible pollution, respect for principles "polluter pays" (Serovic, 2011). For the process of burning and destroying waste by combustion at elevated temperatures in the furnaces, an incinerator is used. Its function is to reduce the mass and volume of waste and convert it to ash that is harmless, where incineration is suitable for waste that is $60 \%$ flammable. This process is suitable for pathological and infectious waste as well as for sharp objects. In developed countries a mobile incinerator MediBurn is used to burn pathological and infectious waste in smaller medical facilities and laboratories. The advantage of this process is that the waste volume will be reduced by some 50 to 400 times. However, incinerator defects go to high costs and risk of pollution, since the burning incinerators used in hospitals produce more furans and dioxins. Construction of incinerators at a distance of at least $100 \mathrm{~m}$ from the medical center implies a chimney facility, all in order to reduce smoke and its impact on pollution. In the countries of the Middle East (Iran, Jordan, Kuwait, UAE, Lebanon, Syria), a new technology for managing hazardous medical waste has recently been introduced. This method involves the crushing of a bag within which there is a medical infectious waste using sharp blades, where the volume of cut waste decreases by $80 \%$. The advantage of this way of managing hazardous medical waste involves using it on the ground and reducing the cost of transporting waste to landfills. From an ecological and economical point of view, the method is reliable, easy to use and maintenance, and environmentally acceptable without harmful emissions into the atmosphere. A team of engineers at the National Laboratory in Texas patented a new technology for better control and treatment of hazardous medical waste. They invented a machine that turns medical waste into municipal waste using a crusher where after the crushing of waste the same is wetted with a disinfectant spray and then immersed in a disinfectant solution. Then, the wet waste is dried using hot gas in the drying chamber and then deposited in the landfill (Shareefdeen, 2012).

In relation to the type of waste, medical waste is treated in several ways:

Table 2: Treatment of medical waste

\begin{tabular}{|c|c|}
\hline Type of waste & Type of treatment \\
\hline Infectious waste and sharp objects & $\begin{array}{l}\text { - Incineration/co-incineration } \\
\text { - Disinfection/sterilization } \\
\text { - Crushing }\end{array}$ \\
\hline Patoanatomic waste & $\begin{array}{l}\text { - Incineration } \\
\text { - Crematoriums } \\
\text { - Burying in cemeteries }\end{array}$ \\
\hline Chemical, pharmaceutical and cytotoxic waste & $\begin{array}{l}\text { - Incineration } \\
\text { - Physical-chemical processes }\end{array}$ \\
\hline Blood, blood products and body fluids & $\begin{array}{l}\text { - Incineration/co-incineration } \\
\text { - Disinfection/sterilization }\end{array}$ \\
\hline $\begin{array}{l}\text { Waste with high contents of heavy metals and } \\
\text { pressure bottles }\end{array}$ & $\begin{array}{l}\text { - Physical-chemical processes } \\
\text { - Return to the manufacturer } \\
\text { - Deactivation before treatment (waste bottles) }\end{array}$ \\
\hline
\end{tabular}

Source: Rule book on medical waste management, 2010. 
Significant threat to collapse health of the population is considered to be and environmental pollution, such as air pollution, water, land, waste generation, low level of sanitary infrastructure, high concentration of hazardous chemicals, low quality drinks in certain areas, etc. (Charapina, Mihailov, 2011). Although the influence of the physical environment on human has been known for a long time, public awareness of environmental dangers has been intensified in recent years, primarily on the impact of air pollution and the risk of damage to lung function and respiratory diseases.It implies the presence of gases which are not inherent in natural composition, where certain substances toxic for the living world, radioactive, and particulate traces influence the development of cloudiness, intensity of precipitation and climate (Kristoforovic-Ilic, 2003). In dry periods of summer, emissions of gases and dust, sulfur dioxide, carbon dioxide, vinyl chloride and benzene deteriorate air quality, and can consequently cause a number of health problems, especially on the respiratory system in humans, and especially in children. Also, the rinsing of heavy metals and leachate water from the body of the landfill causes contamination of water and deposition of metals in the water fauna and poses a risk of deposition in the human body as the end user. In compacted waste at the landfill, anaerobic decomposition of the components creates a landfill gas. Methane is extracted that is lighter than air and tends to get out of the landfill, and it is necessary to ensure its controlled release into the atmosphere. In developed countries, landfill gas, i.e. methane is used to create heat energy and is sold as a renewable source of energy (Ilic et al., 2007). Disposal of medical waste to landfills can be carried out on condition to take precautions measures. The bottom of the landfill must be waterproof, where the waste must be covered daily. Near the site there should be no source or well for drinking, and vector control (rodents and insects) at the landfill itself is also necessary (Medical waste management, 2011).

Medical waste is regularly disposed of by the competent institution, i.e. Central place for the treatment of infectious medical waste according to administrative districts, to the landfill of the district they belong to. However, on the example of the city of Novi Sad, the problem of non-existence of the Regional waste management center represents the lack of an institution in charge of environmental protection and, therefore, of public health. Expansion of the existing landfill and technical improvement of the regional center would solve the current problem of insufficient capacity of the landfill, and thus municipal landfills and waste dumps in Temerin, Žabalj, Vrbas, Beočin, BačkiPetrovac, BačkaPalanka and Srbobranwere closed. According to the data of the Environmental protection agency in Serbia, only 8 regional landfills have been formed, while three are under construction. Landfills were formed in Užice, Sremska Mitrovica, Pančevo, Leskovac, Jagodina, Pirot, Lapovo and Kikinda, but only one - landfill "Duboko" in Uzice has permits for all five waste management activities (collection, transport, storage, treatment and disposal). Waste management strategy from 2003 defined the existence of 29 regional landfills, covering the territory of 160 municipalities. The new strategy for the period from 2010 to 2019 introduced the term "regional centers for waste management" (26 centers) for performing recycling waste separation, transfer stations as well as composting facilities. New, regional centers aim to solve the problem of forming wild dumps and storing garbage on inadequate official landfills (https://www.cins.rs/srpski/ 
research_stories/article/regionalna-deponija-u-novom-sadu-rast-zagadjenja-i-birokratije).

In households, a large amount of medical waste, especially pharmaceutical, is disposed of as municipal waste, where certain pharmaceutically active ingredients contaminate soil and water resources and directly affect human health. In certain countries of the world it is still not recognized the importance of proper management of medical waste, and in Israel there is no low on the disposal and collection of medical waste in the household. Less than $14 \%$ of Israelis return unused and expired drugs to pharmacies (Barnett-Itzhaki et al., 2016). Remains of drugs contaminate purified wastewater which is used for irrigation of agricultural land. Furthermore, the removal of antibiotics into sewage can contribute to the development of resistance to antibiotics among bacterial populations. The pollution of the river by antibiotics is a major problem in today's medicine, because it can lead to infectious diseases and deaths. On the other hand, in other parts of the world, primarily in developed countries there are programs for collecting medical waste in households, as well as in hospitals, clinics, pharmacies.

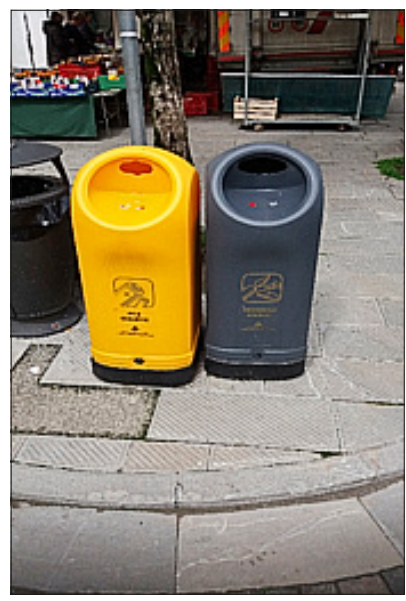

Picture 1. Containers for the collection of medical waste (right) and used batteries (left) in Tolmezzo, Italy.

Source: photo from a private archive of the author of the paper, April 2018.

Producers of medicines and pharmacies pay for the collection and destruction of medical waste from households, respecting the "polluter pays" principle. Today, according to the EU directive from 2001, most European countries provide detailed information on the collection of unused / expired medicines. Information for the safe disposal of pharmaceutical products, users get directly from a pharmacist or a doctor, over the Internet, brochures, information on the outer packaging of each product. Several European countries (Iceland, Estonia, Belgium, Great Britain, Denmark, Lithuania, Liechtenstein, Norway, France, Hungary,Croatia) enforce the legal obligation to collect pharmaceutical waste in pharmacies. In France, medicines that have not expired will be distributed to humanitarian associations. In other European countries (Italy, Ireland, Albania, Austria, Germany, the Netherlands, Luxembourg, Slovenia, Spain, Poland, 
Portugal, Finland, the Czech Republic, Sweden and Switzerland), the collection of pharmaceutical waste from households is carried out by pharmacies on a voluntary basis. In the United States since 2010, unused medicines have been collected from hospitals, clinics, pharmacies, pharmaceutical companies and transported to a medical waste treatment center. The collection, treatment and disposal of medical waste is financed by DEA (Drug administration), law enforcement agencies, pharmaceutical companies based on the principle of "polluter pays", environmental and public health agencies. In Mexico there is no law on the collection and treatment of medical waste from households. However, 23 of the 31 states in Mexico have launched the SINGREM program for the collection and treatment of waste, financed by the Mexican national chamber ofpharmaceutical industry (CANIFARMA). In Colombia, 2010, the program PUNTO AZUL, financed by manufacturers and importers of medicines, was implemented, where the collection of pharmaceutical products is carried out in pharmacies and large supermarkets on a voluntary basis. In the countries of the Middle East there is no legal basis for regulating the issue of adequate disposal of medical waste. Less than $5 \%$ of the population returns unused / expired medicines to pharmacies, and many of them mix the same with municipal waste or throw into the sewage system. In Israel, in 2006, a private pharmacy in cooperation with the Ministry of health initiated a campaign for the collection of unused medicines, in exchange for one vitamin C package (Barnett-Itzhaki et al., 2016).

\section{PLAN DISTRIBUTION EQUIPMENT FOR TREATMENT OF INFECTIOUS MEDICAL WASTE}

According to the model of administrative district, The Ministry of health has established the existence of the Central place for the treatment of infectious medical waste. Each district has at least one health institution, which is also the producer of the largest amount of infectious medical waste (for example: general hospital, public health institutes / institutes). The designated institution has a duty to treat not only its own infectious waste but also the waste that is created in other health institutions from that district. In some administrative districts, a Local treatment was established for the treatment of infectious medical waste, which originates from several smaller surrounding health facilities (for example: health centers, clinics). Infectious medical waste from institutions which are considered to be smaller waste producers is collected and transported to the institutions of the largest waste producer in the administrative district (National guide for the safe management of medical waste, 2008). In SouthBackacounty, the Central place for the treatment of infectious medical waste has the Clinical center of Vojvodina, the Institute of Public health of Vojvodina and the Institute for pulmonary diseases of Vojvodina, Sremska Kamenica. The current situation regarding the treatment of infectious medical waste in these three institutions is that at this moment only its own infectious waste is treated, bearing in mind the insufficient funds from the Ministry of health to treat waste from other health institutions from that district. 


\section{POSSIBLE RISK OF MEDICAL WASTE BY HEALTH OF POPULATION}

It is difficult to measure the effects on the health of the population, bearing in mind that the concentrations of the effects of pollutants, which are present in the waste, predominantly small. However, it is quite safe, based on the large number of papers on the effect of pollutant emissions and epidemiological studies, the existence of certain connections between the resulting diseases and proximity to the location of the waste treatment facilities (Carapina, Mihajlov, 2011). For most studies, waste management facilities are black boxes, which are supposed to emit toxic compounds, but without actual, quantified measurements that could be used in human health risk assessment (Saffron, Giusti, Pheby, 2003). Consequences caused by hazardous medical waste can be acute and chronic. After short-term exposure to dangerous substances, acute consequences occur, among which are burns caused by corrosive substances, eye irritation, inhalation of toxic gases. Chronic consequences occur after long-term exposure, difficult to predict, since they occur after several years, where their cause can hardly be determined (Serovic, 2011).

Improper handling of medical waste represents a potential risk and factor in the spread and transmission on infectious diseases. The risk group of transmission of infectious diseases includes primarily health workers, doctors of medicine and medical technicians, patients, staff employed in biomedical laboratories, logistics staff - hygiene services. This transmission is done through direct contact with the infected person and its body fluids, as well as indirectly through contaminated medical equipment.Precisely, percutaneous injuries are one of the mostimportant risk factor for the transmission of infectious diseases. Percutaneous injuries are divided into two types: injuries to the needles used in therapy and diagnosis and injuries to sharp objects (glass, scalpels). Centers for disease prevention and control from Atlanta in the United States indicate that about 1000 percutaneous injuries occur in hospital conditions on a daily basis. However, it is difficult to estimate the real number of these injuries since most of them are not reported, and an insight into the rate of PP in non-hospital health institutions is unknown (National guide for the safe management of medical waste, 2008). The consequence of percutaneous injuries are microorganisms, i.e. Causes of various infections in humans such as: infections caused by hemorrhagic fever viruses (e.g.ebola), hepatitis B, hepatitis C, herpes, HIV, malaria, leprosy, typhus, syphilis, gonorrhea, diphtheria (Jovanovic, 2014). Bearing in mind the characteristics of medical hazardous waste due to the impact of emissions into environmental media and consequently on the health condition of people, the following indicators of negative health effects, namely, possible risks are listed:

\section{Risk of infection}

Medical waste is a source of potentially dangerous microorganisms that can infect patients, health workers, and the general public. There are several ways to exposure to this risk: through percutaneous injuries, inhalation, ingestion, skin contact or mucous membrane of an infected person. 
Table 3: An example of an infection that can cause hazardous medical waste

\begin{tabular}{|l|l|l|}
\hline Type of infection & Infectious factor & Portable factor \\
\hline $\begin{array}{l}\text { Gastrointestinal } \\
\text { infection }\end{array}$ & $\begin{array}{l}\text { Enterobacteria (Salmonella, Vibrio } \\
\text { cholera, Shigella) }\end{array}$ & Vomiting, excretion \\
\hline Respiratory infection & $\begin{array}{l}\text { Mycobacterium tuberculosis, } \\
\text { Streptococcus pneumonie, SARS virus } \\
\text { (Severe Acute Respiratory Syndrome) }\end{array}$ & $\begin{array}{l}\text { Secretion after inhalation, } \\
\text { saliva }\end{array}$ \\
\hline Eye infection & Herpes virus & Secretion, eye irritation \\
\hline Skin infection & Streptococcus & Pus \\
\hline Antrax & Bacillus anthracis & Sin secretion \\
\hline Meningitis & Neissseriameningitidis & Cerebro-spinal fluid \\
\hline AIDS & Human Immunodeficiency Virus (HIV) & $\begin{array}{l}\text { Blood, sexual secretions and } \\
\text { other body fluids }\end{array}$ \\
\hline Hemorrhagic fever & Lassa, Ebola, Marburg, Junin viruses & Blood and secretion \\
\hline Hepatitis A virus & Hepatitis A virus & Excrement \\
\hline $\begin{array}{l}\text { Hepatitis B and C } \\
\text { viruses }\end{array}$ & Hepatitis B, C viruses & $\begin{array}{l}\text { Blood and other biological } \\
\text { liquids }\end{array}$ \\
\hline Avian influenza & H5N1 virus & Blood, excretion \\
\hline
\end{tabular}

Source: Medical Waste Management, 2011.

Pathogenic microorganisms have limited capacity survival in the environment, which depends of the conditions of the same (temperature, humidity, solar radiation, presence of disinfectants, availability of organic substrates). Bacteria are less resistant to viruses. When estimating the survival time of microorganisms in the environment, the role of rats and insects as passive pathogens should be taken into account, and measures must be taken to control their spread (Medical waste management, 2011). Hepatitis B virus is a very contagious infection due to the high concentration of HBV in peripheral blood in infected persons. Inadequate disposal of body fluids and tissues of infected patients as medical waste increases the risk for both employees and patients, with the possibility of epidemic spread of the disease and on the rest of the "healthy" population. The HBV virus is stable for up to 7 days in dried drops of blood, so that any contact with an unhealthy environment with contaminated blood poses a risk of infection (e.g. hemodialysis units). Hepatitis $\mathrm{C}$ virus is transmitted by a single exposure to large amounts of blood of infected persons (e.g. transfusion of untested blood and its products) or in intravenous injectors of psychoactive substances. Studies show that $1 \%$ of healthcare workers in the United States are infected with HCV and that there is an increased risk of infection resulting from percutaneous injuries (National guidelines for the safe management of medical waste, 2008).

\section{Chemical risk}

Many chemical and pharmaceutical products are used in healthcare institutions. Due to their characteristics (toxicity, carcinogenicity, mutagenicity, corrosivity, explosiveness, inflammability), most of them represents health risks. Different routes of ex- 
posure to these substances: inhalation of gas, contact with the skin or mucous membranes, ingestion. Some substances (chlorine and acids) can create toxic gases when they mix. Examples of hazardous chemicals are disinfectants that are widely used in health care institutions. Most of these are irritating or corrosive, and some disinfectant preparations, such as, for example, formaldehyde is toxic. Mercury is a heavy metal, and it is in liquid form at room temperature and pressure, it is very dense where $1 \mathrm{~L}$ of mercury amounts $13.5 \mathrm{~kg}$. It accumulates in sediments, easily evaporates, and for a year stays in the atmosphere. It is located in thermometers, manometers, certain types of batteries, dental alloys, fluorescent lamps. Health facilities are the main source of mercury in the atmosphere due to the burning of medical waste, which directly affects the pollution of surface waters. Mercury is very toxic and can cause death if inhaled (Medical waste management, 2011). Pharmaceutical pollution in surface waters presents a number of risks for public health and aquatic ecosystems. Consumers contribute to this pollution by using and disposing of medicines in an inadequate way (Vatovec et al., 2017).

\section{Risk of explosion; Risk of radioactivity}

At the UN Environment Conference held in Rio de Janeiro in 1992, it has been concluded that in the world, 5.2 million people, including 4 million children, die from diseases related to waste each year (Emdadul et al., 2012). Later research, according to the World Health Organization regarding the number of patients related to the problem of proper management of medical waste, in 2000 due to inadequately deposited syringes and needles 66,000 cases of Hepatitis B infection, 16,000 Hepatitis C and 200-5,000 HIV infections were reported, predominantly among health workers (Medical waste management, 2011).

\section{RESULTS OF SURVEY RESEARCH}

The survey questionnaire was formed in order to examine the current state of the impact of medical waste on human health, as well as the awareness of respondents to the possible unwanted consequences that medical waste (pharmaceutical waste) can produce if it is treated in an inappropriate manner. The research was conducted in the city (Novi Sad) and the rural area (BackiJarak) in a total of 90 respondents (45 respondents for each area) different sex, age, occupation. During the examination, the focus was on the population of the older age structure, given that they are the biggest drug users. In addition to the basic questions, respondents gave answers about methods the safe disposal of pharmaceutical waste, the type of drug they possess, the disposal of unused medicines and their impact on public health and the environment, as well as taking responsibility for the safe management of pharmaceutical waste. A questionnaire of fourteen questions was conducted in the period from 10-25. June, anonymously, based on a classic printed questionnaire, which involves personal contact with the respondents, by random sample method. 
A total of 90 respondents took part in the survey. In the rural area (BackiJarak), 20 person were male and female, the following age structure: 4 persons aged up to 30 years, 9 persons aged 31 to 40, 2 persons aged 41-50, 12 persons aged 51-60 and 18 persons aged over 60 years. The majority of respondents are employed ( 22 persons) followed by elderly persons - pensioners (19 persons) and the other 4 respondents are not employed. The vast majority of respondents live in the household with three or two members (18 or 12 respondents).

In the city center, in Novi Sad, were interviewed 22 male people and 23 female persons the following age structure: 3 persons age 31 to 40,6 persons aged 41-50, 6 persons aged 51-60 and 30 respondents over 60 years.The majority of respondents are older persons - pensioners ( 30 persons), followed by employed people (14 persons) and one respondent without a working relationship. In the city center, $40 \%$ of the respondents live with one family member, and $33 \%$ of them in a two-member family.
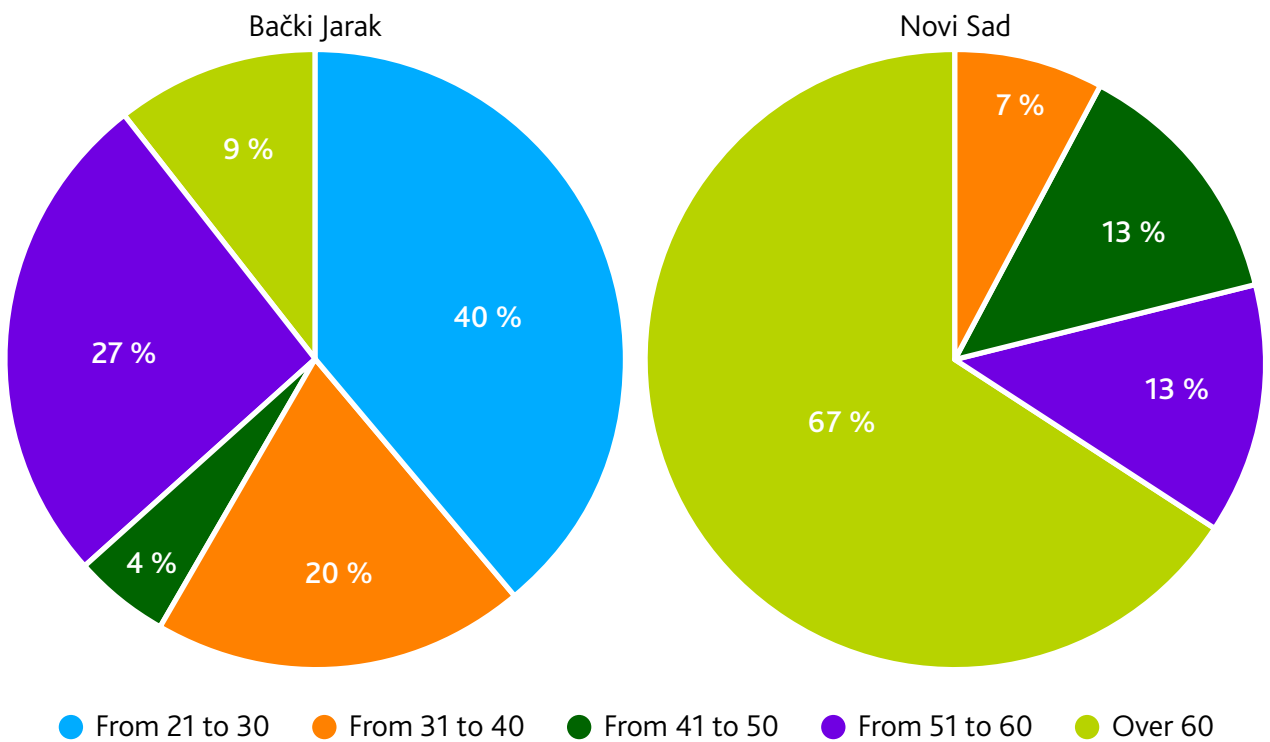

From 21 to 30

From 31 to 40

From 41 to 50

From 51 to 60

Over 60

Chart 1. Age of respondents

Ask whether they take medicines free or prescription when they go to the pharmacy, a large number of respondents answered that they are taking prescription medicines (57,8\% - rural and $48,9 \%$ - the city center), while $42,2 \%$ of the respondents take their medication free of charge in BackiJarak and 22,2\% of the respondents of Novi Sad. Medicines taken on prescription orfor free, respondents in the rural area kept in the bedroom $(35,6 \%)$, in the kitchen $(26,7 \%)$, in the cupboard in the bathroom (13,3\%), while the respondents in the city center kept in the kitchen (26,7\%), the bedroom $(26,7 \%)$ and a living room (20\%).A small number of respondents medicines kept in a bathroom cabin (11.1\%) or in a refrigerator (2.2\%), out of the reach of the younger population. Regarding the type of medicines that are possessed by $46.7 \%$ of the respondents, in the rural area, use medicines for regulation of blood pressure, analgesics (44.4\%) and herbal prepara- 
tions. In the same percentage, respondents in the city responded that according to the current state of health, the most of them used medicines for regulation of blood pressure (46.7\%), followed by the use of analgesics of $44.4 \%$ and herbal preparations in the remaining percentage.

When asking whether they have medicines that have expired and unused drugs, over $80 \%$ of respondents in both areas responded that they do not have such medicines, and they believe that the information they need about how to dispose of pharmaceutical waste should be obtained by pharmacists (55.6\% in the rural area and $35.6 \%$ in the city), with the medicines specification (42.2\% of respondents in BackiJarak), followed by of doctors / clinics, $28.9 \%$ of respondents in Novi Sad, as well as through the media $(26.7 \%$ - city center, $15.6 \%$ - rural area). A certain number of respondents $(42.2 \%$ of the respondents in the urban area, over $51.1 \%$ in the rural area) who possess medicines with expired and unused medicines, throws them in a garbage can, mixed with municipal waste and without prior separation deposited on a city dump. Other respondents (50\% - rural, 56\% - city area) who answered to the previous question that they do not have unused or expired medicines, use all the medicines on the basis of prescribed therapy or return them to the pharmacy. A small percentage of respondents in the urban area (less than 5\%) decide that unused and expired medicines burned or stored in a hazardous waste collection facility. In the opinion of the respondents, the best way to safely dispose of pharmaceutical waste is to return it to pharmacies (68.9\% of rural respondents and $60 \%$ in the city area) or to store it in a specific hazardous waste facility ( $13.3 \%$ of respondents in both areas ) if it exists at a site known to the public.

According to the Likert scale, on the basis of the stated claim that unused medicines and medicines with an expired date pose a potential danger to public health and the en-
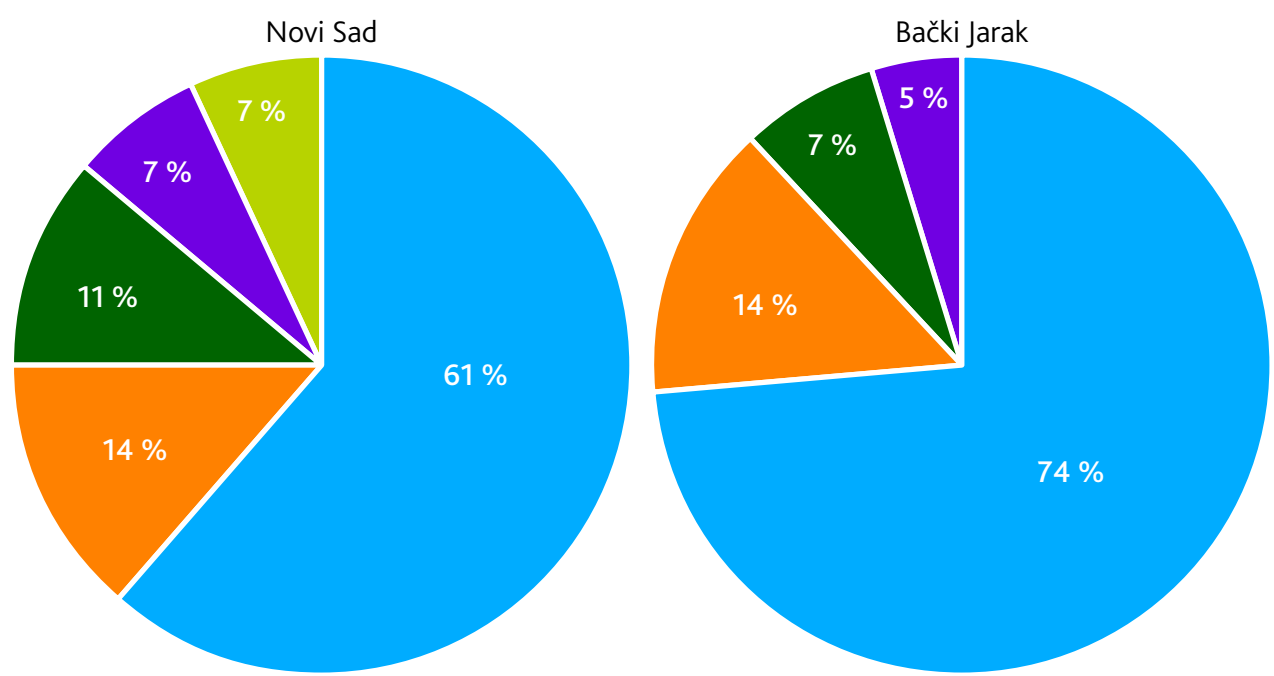

Return to pharmacy

Hazardous waste facility

Return to the doctor / hospital

Recycle

Municipal waste

Chart 2. The best way to safely dispose of pharmaceutical waste 
vironment, over $80 \%$ of respondents in both areas agree with that position. $42.2 \%$ of respondents in the urban areas and $33.3 \%$ in rural areas stated that they are still not sure about the issue and the assertion about the availability of information on safe storage of pharmaceutical waste by relevant public opinion institutions, while $37.8 \%$ of respondents in BackiJarak, and $24.4 \%$ of respondents in Novi Sad do not completely agree with this statement in the survey paper. According to a statement about the existence of a certain place in the pharmacy and a medical facility for the disposal of medicines, $46.7 \%$ of the respondents in the rural area and $35.6 \%$ in the city area is not completely safe for the existence of a certain place in medical facilities for the disposal of medicines. About $26 \%$ of respondents in Novi Sad and 20\% of respondents in BackiJarak do not completely agree with the stated claim about the existence of a separate place for disposal of pharmaceutical waste. Based on that statement that the destruction of medicines should be carried out in incinerators, i.e. by burning process in Serbia, more than half of the respondents (over 50\%) in both areas agree with this statement, while the remaining respondents (35.6\% - rural, $20 \%$ - city center) in relation to the said claim and such treatment of pharmaceutical products. During interviews with respondents, a part of the interviewed persons emphasized the importance of controlling the technology of the burning process and expressed concern about the amount of harmful gases that goes into the atmosphere during the treatment in the incinerator, and thus pollute the environment. More than $50 \%$ of respondents (62.2\% - rural, $51.1 \%$ - urban) partially or completely agree with the claim that unregulated landfills are not safe enough and pose a risk of possible spread of infection.

More than 70\% (82.2\% of respondents in BackiJarak, $71.1 \%$ of respondents in Novi Sad) disagree at all with the statement that containers for disposal of medical (pharmaceutical) waste were placed in public places.

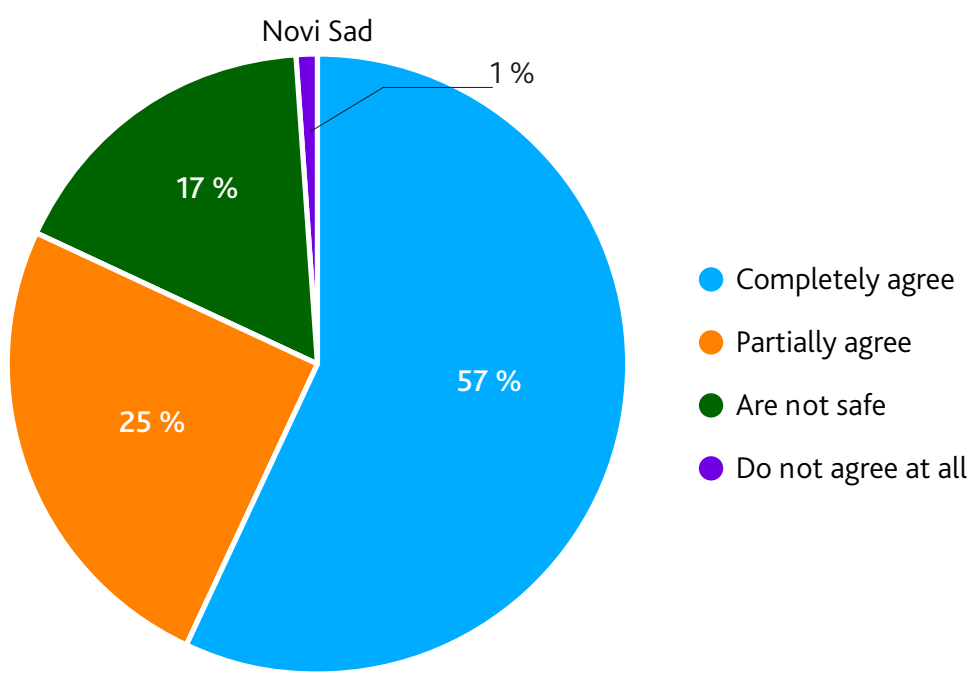

Chart 3. Unsafe of landfills, a place of possible spread of infection 


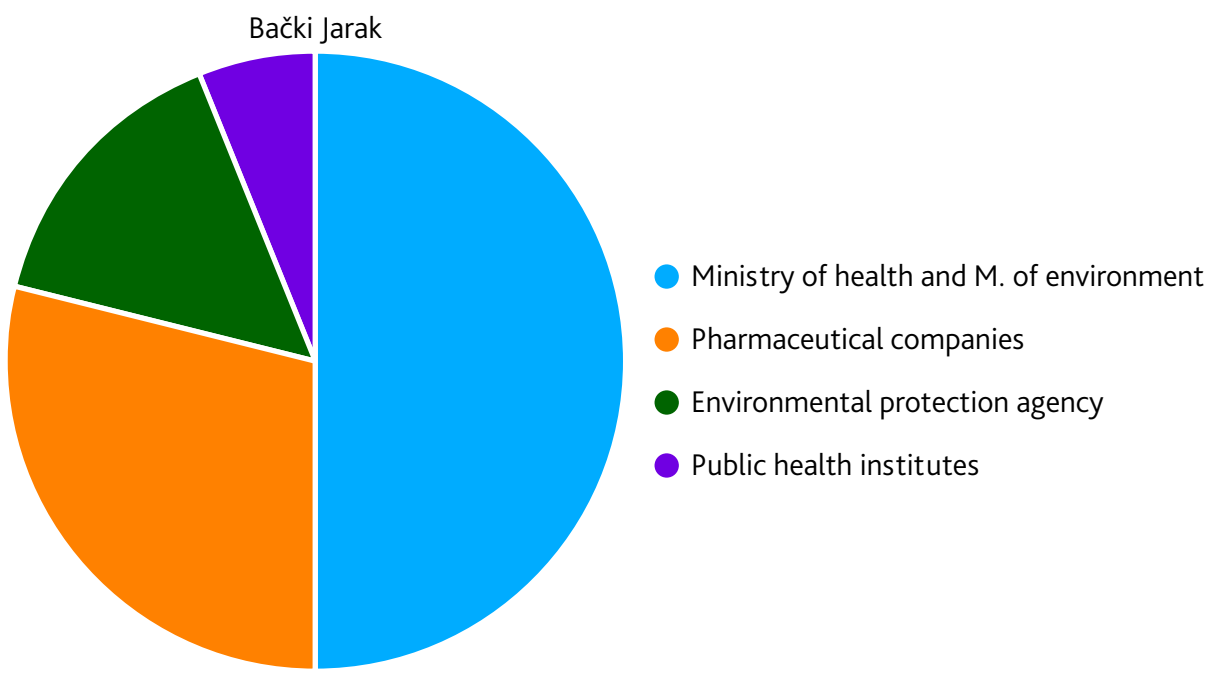

Chart 4. Take responsibility for the safe management of medical (pharmaceutical) waste

The responsibility for the safe management of medical waste, according to the opinion of the respondents in both examined areas, should be taken by the Ministry of health and the Ministry of environmental protection (57.8\% - the rural areas, $46.7 \%$ the city center), followed by pharmaceutical companies - drug manufacturers (33.3\% of respondents and BackiJarak, $46.7 \%$ of respondents in Novi Sad), followed by Environmental protection agency (28.9\% - urban area, $17.8 \%$ - rural area)

The vast majority of respondents to the last question about theirreadiness to store medicines at a suitable location, responded that they are very ready to take and implement measures (86.7 - city area, $80 \%$ - rural area) or are somewhat willing (13.3\% in both examined areas).

\section{CONCLUSION}

The problems of treating medical waste should be addressed by adequate application of the legislation, implementing international regulations in the area of environmental protection and the health of the population. The Republic of Serbia, primarily state institutions in charge of environment and human health, do not adequately manage medical waste at landfills (medical waste is mixed with municipal). Unfortunately, insufficient support to the Ministry of environment as a result in a small number of accomplished goals in the field of environmental protection, and consequently in the field of public health promotion. Namely, in Serbia, for a long time, the annual allocation of GDP for environmental protection is less than $0.5 \%$, which is far below the EU average of $2 \%$. We agree that society can not, without technological progress, and based on the recommendation of the World Health Organization in the future it is necessary to use one of the methods for the treatment of medical infectious waste based on sterilization with water 
vapor using autoclave. After the sterilization process, in order to reduce the volume of sterilized waste and reducing the amount of packaging needed for transport, complete destruction is necessary, namely, shredding of sterilized waste to non-recognition (parts not exceeding $1-2 \mathrm{~cm} 2$ ). In addition, it is necessary to develop and implement the National Plan for adaptation to climate change and the National Strategy for the Protection of Air, as well as the permanent disposal of hazardous substances with the help of built facilities for the destruction of hazardous chemicals.

The issue of the health risk of the population needs to be solved on the basis of other activities and measures such as:

- Introduction of biomarkers in epidemiological research, as organic indicators of changes in environmental protection or health of the organism

- Introduction of measures to minimize waste generation (prevention of waste generation) encouraging reuse and recycling, and finally proper waste disposal

- Encouraging and public participation when making decisions about the waste management system

- Encouraging the use of waste as an alternative fuel in cement, ironworks and thermal power plants - heating plants

- Remediation of existing dumpsites, sources of greatest environmental risk

- Introduction of separate collection and treatment of hazardous waste from households and industry

- Construction of 12 regional waste management centers

- Providing incineration capacities

- Reducing waste on landfills up to $20 \%$

Public health policy should affect the achievement of certain goals such as: prevention of exposure to medical waste; informing the public about the risks of medical waste by focusing on people employed in landfills, families of patients who are being treated at home, patients of health institutions; encouraging responsibilities among patients and visitors to health facilities related hygiene and medical waste management.

\section{REFERENCES}

Ali Khan, J. (2006): Hospital waste management issues and steps taken by the government of Pakistan. Ministry of the Environment, Pakistan.

Barnett-Itzhaki Z., Berman T., Grotto I., Schwartzberg E., (2016): Household medical waste disposal policy in Israel. Israel Journal of Health Policy Research, Vol. 5, No. 48.

Bozic, I. (2013): Waste Management at the Agency for Medicines and Medical Devices of Serbia. Agency for Medicines and Medical Devices of Serbia, Belgrade.

Emdadul H. Syed, Mahmuda Mutahara, Mosiur Rahman (2012): Medical Waste Management in Dhaka, Bangladesh: It's a Review. Home Health Care Management \& Practice, Vol. 24, No. 140-145.

Ilic, P., Tepic, S., Eric, Lj. (2007): Municipal waste landfill as a source of pollution and impact on human health. Materia Socio Medica, Vol. 19, No. 1. 
Jovanovic, M. (2014): Problems of disposal of medical waste in the Republic of Serbia.Faculty of Technical Sciences, Cacak.

Kristoforovic-Ilic, M. (2003): Hygiene with medical ecology. Ortomedics, Novi Sad.

Law on Waste Management (“Official Gazette of RS", No. 36/2009, 88/2010, 14/2016).

Medical Waste Management (2011). International Committee of the Red Cross, Switzerland.

National guide for safe management of medical waste, 2008. Ministry of health of the Republic of Serbia, Belgrade.

National Waste Management Strategy (2003).Ministry for the protection of natural resources and environment.

Rulebook on the management of medical waste ("Official Gazette of RS", No. 78/2010).

Rulebook on the conditions and manner of classification, packaging and storage of secondary raw materials ("Official Gazette of the Republic of Serbia", No. 55/2001).

Saric, L., Knezevic, B. (2009): Quantification of eco-impacts in the area of hazardous waste management. 1st International Conference, Ecological Safety and Post-Modern Environment, Banja Luka, RS, BiH.

Saffron, L., Giusti, L., Pheby, D. (2003): The human health impact of waste management practices. Management of Environmental, Vol. 14, No. 2, pp. 191-213.

Serovic, R. (2011): The impact of waste on health, Ministry of agriculture and environmental protection, Belgrade.

Serovic, R. (2011): New legislation in the RS, Medical waste management. Ministry of environmental protection, Belgrade.

Shareefdeen, Z. (2012): Medical Waste Management and Control. Journal of Environmental Protection, Vol. 3, No. 1625-1628.

Stevanovic-Carapina, H., Mihajlov, A. (2011): The impact of waste on the urban population - contribution to the establishment of cause-and-effect relationships. Recycling and Sustainable Development, Vol. 4, No. 20-28. University of Belgrade, Technical Faculty in Bor, Belgrade.

Transportation and treatment of infectious medical waste (2009). Institute of Public Health of Serbia "Dr Milan JovanovićBatut", Belgrade.

Vatovec C., Van Wagoner E., Evans C., (2017): Investigating sources of pharmaceutical pollution: Survey of over-the-counter and prescription medacation purchasing, use, and disposal practices among university students. Journal of environmental management.

Waste Management Strategy for the period 2010-2019. (Official Gazette of the Republic of Serbia, No. 29/10).

http://ec.europa.eu/echo/files/evaluation/watsan2005/annex_files/WEDC/es/ES08CD. pdf

https://www.cins.rs/srpski/research_stories/article/regionalna-deponija-u-novomsadu-rast-zagadjenja-i-birokratije 